\title{
It is my Cross
}

\section{Makhmudova Svetlana Musaevna}

Full Doctor of Philology, Head of the department of Dagestanian languages, Dagestan State University Corresponding author's mail: rutulsveta@mail.ru

Doi:10.5901/mjss.2015.v6n6s2p236

\begin{abstract}
History of Caucasian peoples is one of the least studied branches of science. Though, there are some lexical signs for future research. With the help of etymologic analysis and comparative method we are able to analyse the words, semantics of which is unclear from the point of view of the present. These methods allow the scientists suggest hypotheses for the word's etymologic analysis. The objective of this paper is to highlight the topic left out by researchers: many Dagestan peoples had been professing Christianity from $313 \mathrm{AD}$ (introduced by the king Urnayr) up to the 19th century. The Rutuls are among the peoples which were first to accept Christianity (maybe even the first, according to some sources): in 90 AD in Rutuls settlement Kish, Shaki Khanate, Saint Elishe built the first Christian church. Majority of the Kish population were the Rutuls. The Christian period in the history of Dagestan peoples was undeservingly forgotten since 1836 when the King abolished Albanian Apostolic Autocephalous Church. Though, at the present period of religious extremism and odd religious intolerance it would be useful to remember that for more than a thousand years Dagestan peoples had been professing voluntarily accepted Christianity. The loss of this religion led to the loss of spiritual origins of Caucasian culture, literature and ancient history.
\end{abstract}

Keywords: Rutul language, vocabulary, history of Rutul religion, Jews in the history of Rutul, artefacts, cave drawings.

\section{Introduction}

Rutul language belongs to Lezgic group of Northeast Caucasian language family. It is spoken in Northwest of Dagestan and North of modern Republic of Azerbaijan in following settlements: Rutul, Amsar, Boch, Novuy Boch, Shinaz, Khinov, Kala, Ikhrek, Aran, Luchek, Vurush, Djlikhur, Mukhrek, Tsudik, Kiche, Kufa, Khnukh, Fucukh, Una, Kina, Pilek (Dagestan; villages Natsma and Fartma are now abandoned); Kish, Shin, Kainar, Shorsu, Dashjuz, Aidynbulakh, Khyrsa (Azerbaijan, territory of historic region of Caucasian Albania, which was called Gal by the Rutuls). The Rutuls are also the major part of population of town Sheki in the Sheki Rayon and Qax Rayon in modern Azerbaijan.

The history of ancient Caucasus and its peoples is a mystery for scientists due to absence of written sources. Though, some information about the history of people can be drawn from the language itself, from its vocabulary, anthroponymy, toponymy etc. This paper presents an effort to gather information about the people through studying the Rutul language, which until 1991 had not had written language. This feature allowed it to preserve archaic features and historic evidence.

Rutul language presents interesting evidence which can shed light over some periods of the history of Rutulspeaking people. Under the absence of written artefact, the language is the only source of information for scientists.

\section{Word's Etymologic Analysis}

Our research of language material shows that the most of Rutul words are not accidental. The most etymologically interesting are the words with no possibility to trace their semantics at present.

Example: Nin - 'mother' in Rutul. In Sumerian 'nin' is a 'mistress, sister, queen'. Nintu - Sumerian mother goddess. Aside - a dish cooked by modern Rutuls for women in labour (comp.: Lezgian word isida with the same meaning). Ishtar - Sumerian goddess of fertility. (By the way, the Tsakhur language preserved traces of presence of Ishtar: istar 'fiancée, daughter-in-law' in Tsakhur).

In Rutul Rayon there is a mountain called Tsek'ul (Ц1екьул; lit. 'fire head'). This mountain is sacred for Shinaz people, they worship it as a god. Let us remember that "Caeculus is a legendary founder of Latin town Praeneste, kin to roman Cacus. Caeculus considered to be the son of Vulcan" [Nemirovskiy, 2007].

In Rutul each family and clan has their own name, etymology of which from the present point of view is unclear and hard to explain. Though, one of the ancient families is called the Caries (Карии). Carian language belongs to the group of 
South Anatolian languages. [Ivanov, 2001].

One more ancient family - Dakuy (Дак1уй), close to them - other family, Myzyy (Мызый). There used to be countries of Dacia and Mysia in the Western Asia. In the upper part of Rutul there are settlements of the Ket family. According to S. Starostin, relations between North-eastern Caucasian group of languages and languages of the Ket on the Yenisei River (as well as with the Sino-Tibetan languages) could have existed. Khinalug people also call themselves the Ket: their language belongs to Lezgian group and they are located on their native territory - Albanian land.

The territory of ancient Licia in different times was under the reign of the Pelasgians, the Rutuls, the Arcadians etc. Also people called Siculs lived there. In present Rutul there is a family called Sykylyy (Сык1ылый). The name of the other family Falyy (Фалый) should be related to the Palai people - one of Hurrian peoples.

Ancient family of Gabga (Габга) lives in Rutul - such surname can be met in Spain.

The Rutuls are one of the first ancient people to adopt Christianity (in 70s AD). The first Christian church in North Caucasus was built in the Rutul settlement Kish in Caucasian Albania. Later this church became a centre of Albanian Apostolic Autocephalous Church. Albanian historian Movses Kaghankatvatsi tells in his "History of the Caucasian Albanians": " ... inspired by the Holy Spirit, Saint James, Brother of the Lord, the First patriarch of Jerusalem, imposes hands on Elishe. Elishe received inheritance on the East, headed from Jerusalem to Persia, and visits the Maskuts, ..., and starts to preach in the region of Choga, and by teaching in many places he let many find salvation. From there he came to the region of Uti, the town of Sogarn with three disciples, relatives of which (some of them unrighteous people) began to pursue them, and one of five disciples was martyred. Other two disciples left Blessed Elishe and followed the men - the murderers. But saint Primate arrived to Gis [Kish] and founded a church where bloodless sacrifice was made. At this place first our churches appeared, and metropole and enlightenment".

\section{Church in Kish}

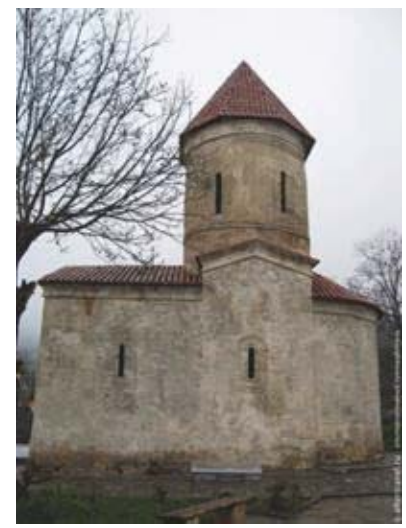

Therefore, James, the brother of Jesus Christ, sends Saint Elishe to preach Christ on the East. This church is still can be seen in Kish and is called Church of Saint Elishe. In Rutul the name Elishe transformed into modern Erish (Epum). Possibly, even the name of Tsakhur Khanate on the territory of Ancient Albania - Ilisu (Илису) (in Tsakhur and Rutul languages - Jilisu (Йилису) - is based upon the name Elishe.

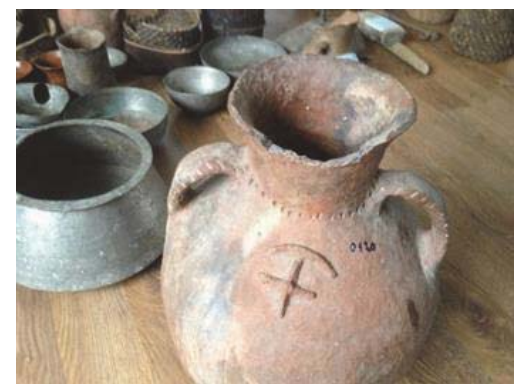

A jug from a burial ground in Rutul. 
At present traces of Christian past can only be found in the language and ancient cave drawings.

\section{A drawing of a church on a rock in Rutul.}
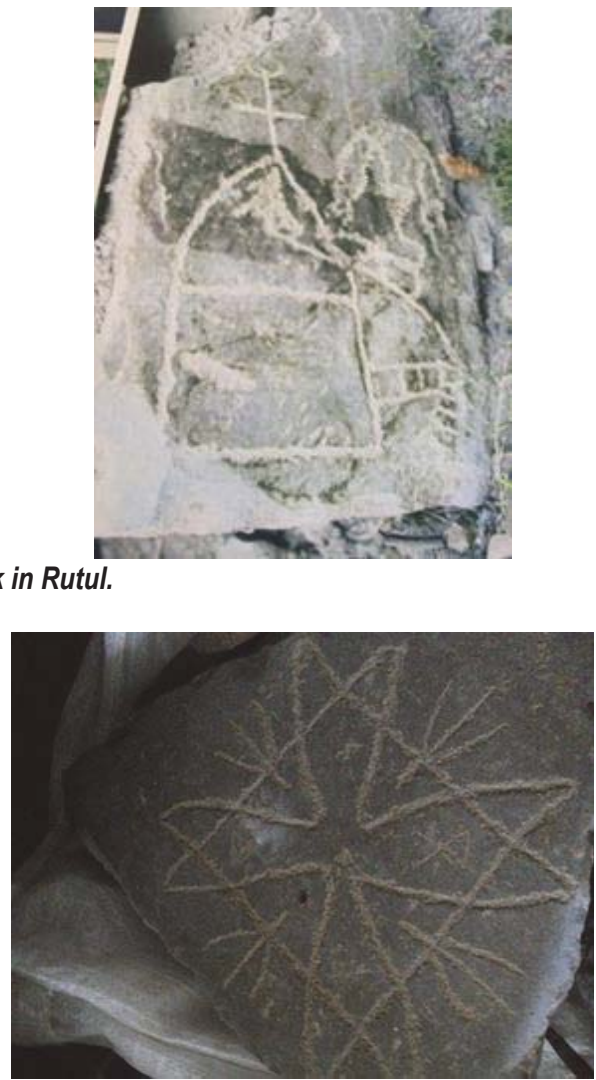

\section{A drawing of a cross on a rock.}

\section{Photo by: Gasanov B.K.}

In 313 AD the Rutuls as a part of Caucasian Albania officially adopted Christianity. At present the Rutuls are Sunni. Though, in Rutul vocabulary, in carpet patterns and scarcely studied cave drawings (which are plenty in Rutul settlements) there are traces of Christian period in the history.
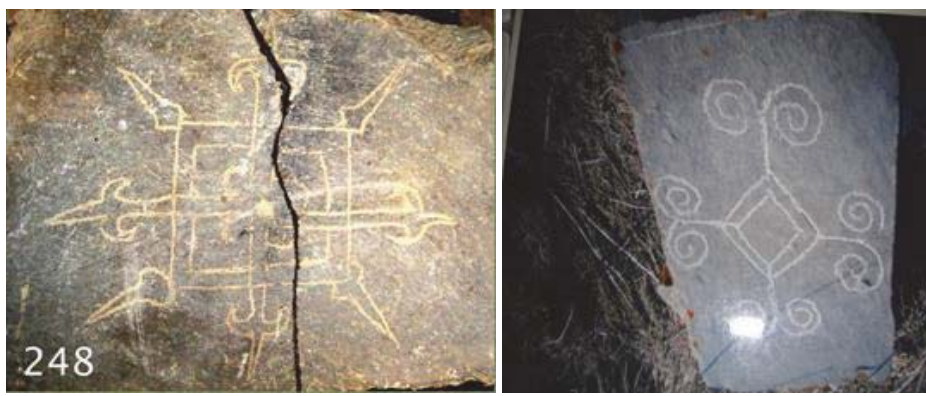

\section{Rocks from Shinaz. Photo by: R. Ramazanov.}

"A cross" in Rutul language - khach (хач), "a church" - kilise (килисе), "a coffin" - gur (әур), "Christian churchman" kashish (ка1шиш). 


\section{A cross on a rock in Shinaz village.}

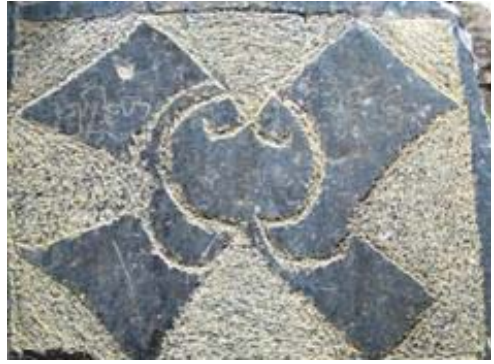

Wreck of a church in Yicha village.

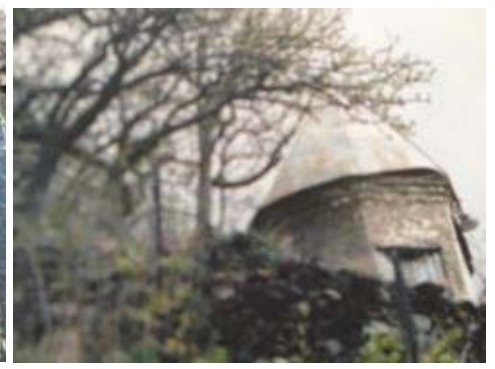

After research of Christian period in Rutul history it is obvious why phraseological unit G'a izdy khach yiі (Гьа изды хач йиъu) - "It is my cross" - in Rutul has the meaning "it is an object of worship and adoration for me", whereas in Russian this ph. unit ("It is your cross") means "it is your hard burden", even though Russian people are Christians at present.

Researchers found following round stones in Rutul settlements. They were, most probably, used to impress the sign of cross:
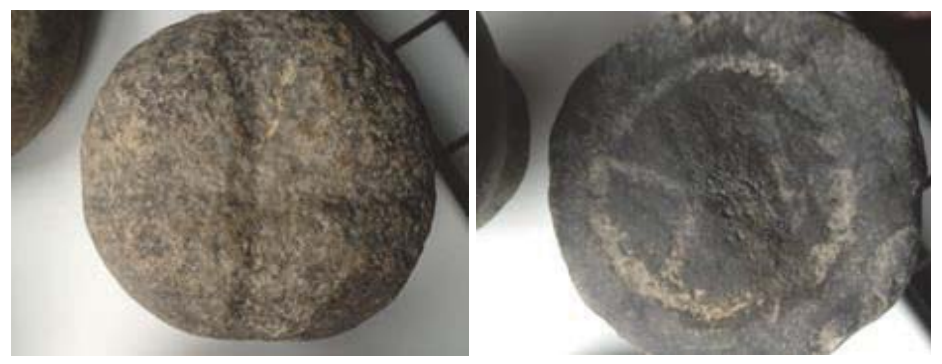

Before transition of Rutuls to Islam, they professed Judaism along with Christianity: in some Rutul settlements there still are cave drawings of an hexagram star. People call there settlements Judicial, even though officially they are Rutul.
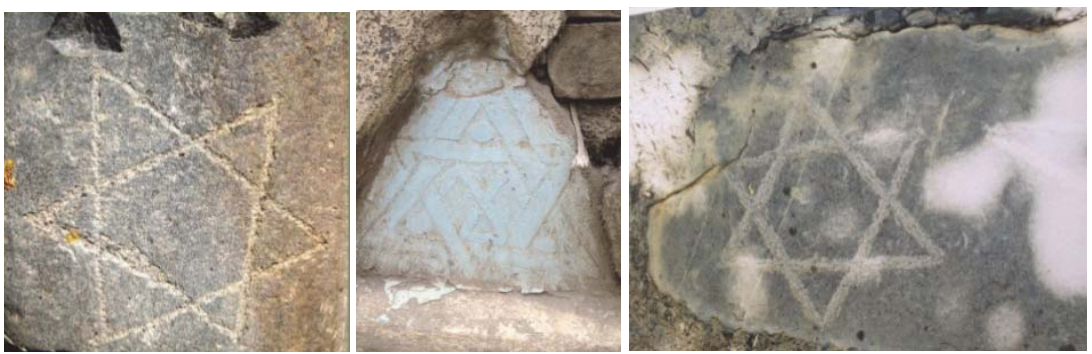

Several Rutul and Tsakhur settlements in Rutul Rayon are called Jewish by older generation. They are: Kala, Mukhrek, Djilikhur (Rutul villages), Gelmets, Muslakh (Tsakhur villages) and several others. There is even a legend telling about one of the first Christian preachers being put to death in Gelmets. There are also anthroponyms going to Classical Hebrew: Adam, Afraim, Abraham, Ishmael, Yivizar//(lizar//Elizar), Jabrayil, Nazar, Lazar, Nukh, Suleiman etc.

F.J. Mammadova, famous historian and author of many foundational works on history of Caucasian Albania, quotes Bar Hebraeus (Syrian bishop, author of "General History") who tells about events from Bible days to 1285: "... The Egyptians were conquered by the Persians again... Okoz [Artaxerxes] also conquered the Jews and made them tributaries. He settled them on the Caspian shore in the town Hyrcania". F.J. Mammadova continues: "This event dates the $4^{\text {th }}$ century BC. This expert gives us valuable data about Jewish (old Hebrew) settlement on the Caspian shore". [Mammadova, 2006]. In Rutul language Йupe // Hirg is the word to denote Lezgians, and this lexeme can be the root of word Hyrcania. 
This explains presence of Jews on the territory of ancient Caucasus. However, Albanian and Jewish peoples are, quite likely, strongly interconnected, as a symbol of Star of David is quite common. Also, name of Rutul family Nazaryy (Назары $\breve{)}$ ) and patronymic Nazar (Назар) in this case can be associated with the fact that ancient Rutuls (Albanians) knew the Nazarenes.

\section{A gravestone of Hasan Jalal-Dawla.}

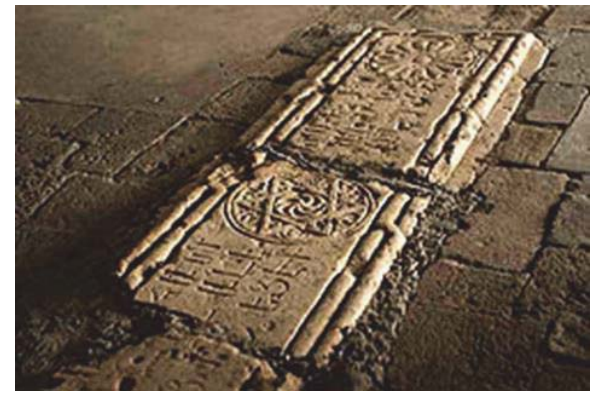

Star of David, symbols of the sun and rolling star are common symbols in Dagestan as well as in modern Azerbaijan in the territory of historical Caucasian Albania. They are depicted on the gravestone of Hasan Jalal-Dowla - Albanian king, buried in Gandzasar.

\section{A stone from Shinaz. Photo by: R. Ramazanov}

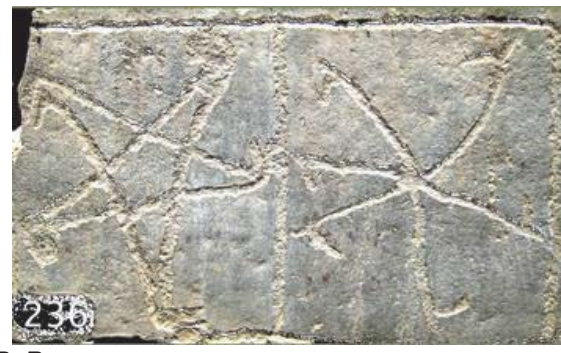

According to the older generation, churches, synagogues and mosques had been coexisting in Rutul settlements up to the $19^{\text {th }}$ century and were destroyed only after revolution. Witnesses tell that in magal (village) Kurasura in Rutul village there used to be a synagogue, later turned into a church and then into a mosque. People still remeber the places where the churches and synagogues used to be.

Movses Kaghankatvatsi mentions Albanian saint Eleazar/lizar [Kaghankatvatsi II, 45]. In Rutul villages there is a name Yivizar (Йивизар), probably, going to llizar.

Old people tell that a square stone still standing on the godekan (main square) of the village, used to have a special meaning during a Christian period. Though, we failed to find out what that meaning was.

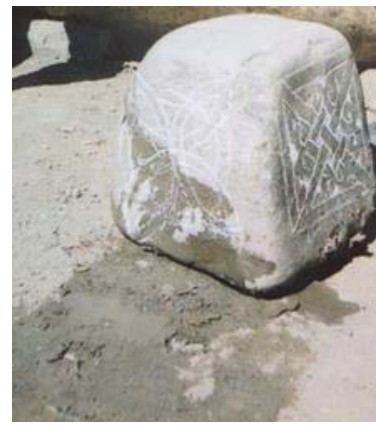


In the territory of Artsakh, Gandzasar in Nagorno-Karabakh there are well preserved gravestones with depictions of a cross and several other pre-Christian symbols with floral ornament. Most of them are complemented with written messages in Armenian language. In Armenia they are called khachkar (cross-stone), in Azerbaijan - khachdash. Albanians, obviously, knew how to work with a rock, which served them for writing. Such khachkars can be found in Tsakhur village Attal of Rutul Rayon in modern Dagestan. These stones also have Armenian inscriptions, floral ornaments and two sun symbols in the upper part. This monument was, apparently, created in late Islamic period as there is no cross inside, but the perimeter of the stone is ornamented with a cross divided by halves. The inside part where the cross usually is - has an inexplicable pattern made with black paint. In the bottom there is an inscription in Armenian.

Historian Aleksidze Z.N. translated this Armenian writing as follows: literally "This cross is a monument".

Obviously, the master-stonemason was literate and still professed Christianity, but probably could not express it openly due to victory of Islam over Christianity. So he expressed his grief through black paint and a broken cross. Yet while, he wrote "this cross is a monument" being sure that this Armenian writing would not be understood.

\section{This cross is a monument.}

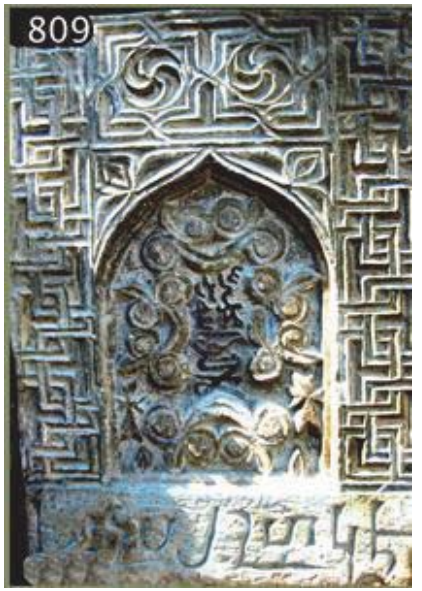

\section{Tsakhur khachkar. Vil. Attal. Photo by: R. Ramazanov.}

In modern Dagestan there are quite many inscriptions in Armenian. After even a trivial search we found one more obviously ancient inscription in this language:

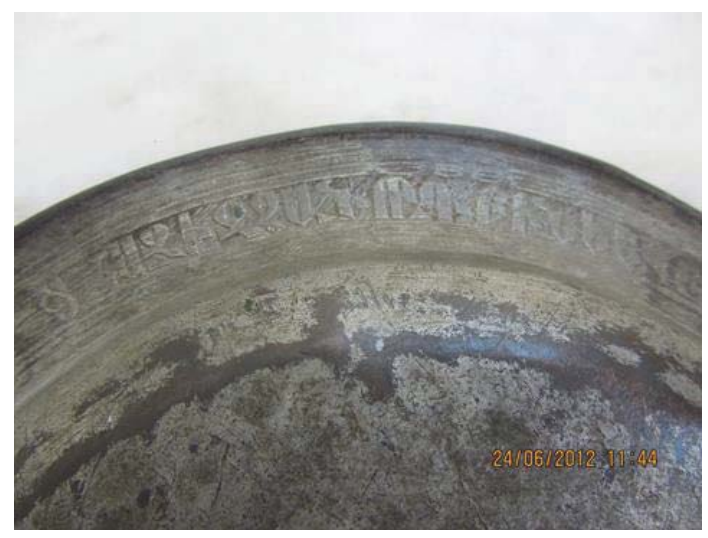

(This copper dish is stored in a private museum of $F$. Chalaeva.)

Aleksidze Zaza, a famous scientist and an expert in ancient writing, one of the authors of Russian translations of 
the Sinai manuscripts, deciphered this inscription for us: "Several graphemes are written with ligatures, creating an impression of unknown writing. In Armenian it is read as follows: Uqhqquin npqh Fhilik... (The son of Azizjan Binke...). I have some doubts as to the letter, because it is not wholly preserved and badly visible."

In ancient burial ground in Rutul researchers found some coins that can be Albanian, as Rutul language has a word for money - shig'ibyr (щигьибыр). This fact might prove that Caucasian Albania had monetary unit.

\section{Shig'ibyr 'money'}
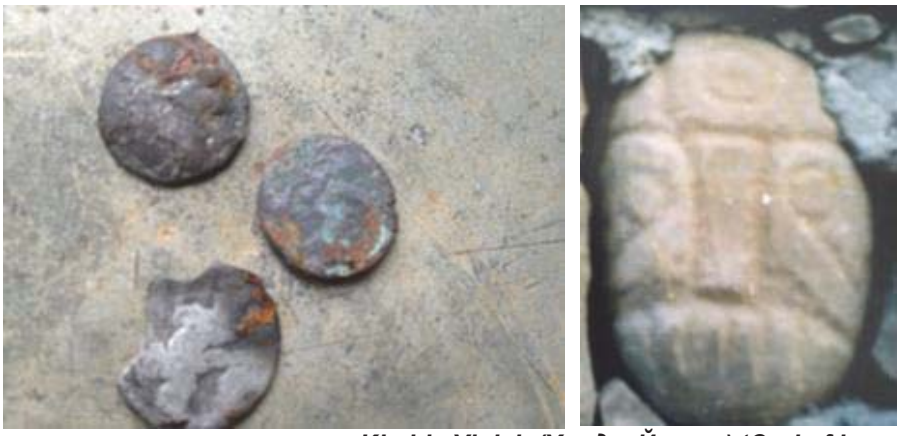

Khaldy Yinish (Халды Йиниш) ‘God of home’

In the territory of Rutul Rayon in Dagestan there are even more ancient silent evidences of history of people and religion. In the remains of a house a stone was found: it represented a face of an ancient god called Khaldy Үinish (Халды Йиниш) - 'god of home'. This deity may be a guardian of hearth and home. Obviously, people preserved respect towards this deity as at present this stone is located in the wall of an ancient church that was later turned into a mosque and united all the major religious beliefs of Rutuls.

On an ancient tower in the Mukhrek settlement there is one more drawing- an evidence of a period of sun-worship. In Rutul language there is a word Shamyy (Шамы $\breve{)}$ - a goddess of Sun.

\section{Sun sign.}
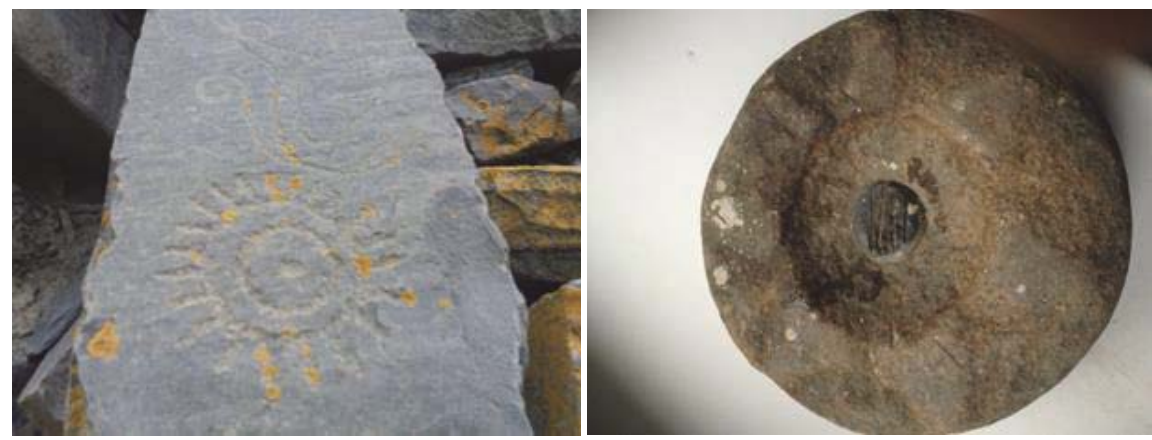

A stone for impression of the sun sign.

Rutul language has an old phrase "Jaala kh'u' (Джаала хьуъ)", having modern meaning of "before, in ancient times, traditionally". Literally it means "before Jala". What Jala is mentioned?

In his work A.A. Kudryavtsev tells: "Toponym of early middle-ages Chor, Jor, Jol used to mean 'the gates' of Derbent in Armenian, Georgian and Albanian sources. It is preserved in the name of Jalgan mountain, on the spurs of which the town is located, ..., as well as in Dagestan languages where Derbent is still called Churul (Lak), Chulli (Dargin)" [Kudryavtsev, 1982]. Rutul language preserved the name Jal (Джал) - ancient Rutul name for Derbent. Thus, abovementioned Джаала хьуъ means "before Jal appeared" or "before Derbent was founded". Expression Джаала хьуъ means the 'very ancient times'.

In the museum of Rutul village there is a copper dish with Albanian inscription, a Star of David, other symbols and an animal with wings and a dog's head. This dish can complement a list of known findings with Albanian inscriptions: 


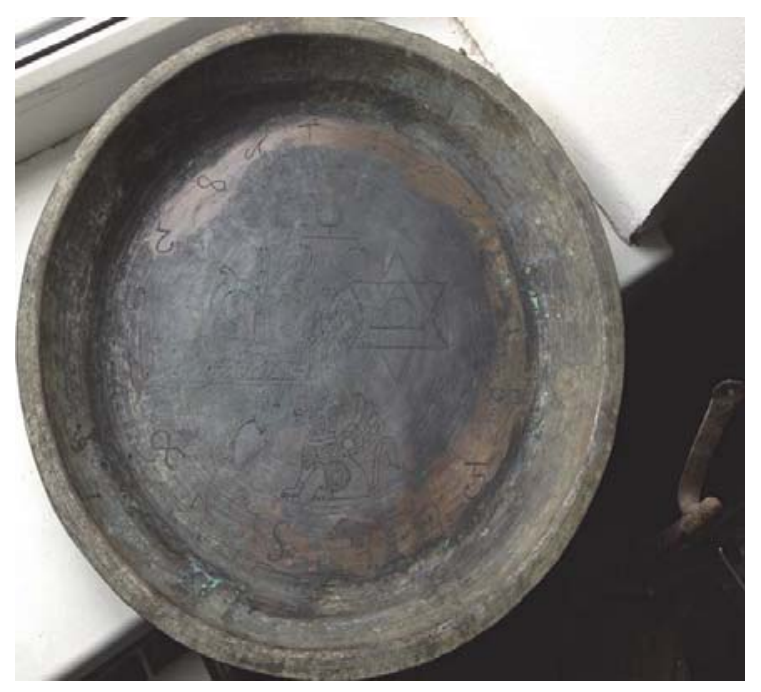

This copper dish was found in May 2015, in village Rutul, Rutul Rayon, Dagestan. There are several interesting symbols in the centre and an inscription in old Albanian language along the perimeter. Georgian scientist R. Lolua identified the symbols as the Nemesis' scales, Calvary, the Star of David and the Griffin - ancient symbol of power over the heavens and the land.

All along the perimeter of this ancient dish there are letters of Albanian alphabet.

V. Schulze, a professor and an expert in Caucasian Albania, confirms that the inscription is in old Albanian language.

Thus, this dish is an important contribution to the study of Albania as it presents one more artefact in a little-studied language.

Southern Dagestan used to be a part of Caucasian Albania, but until present it was not studied by archaeologists and researchers of Albania. We suppose that here we shall find much material on copper utensils and stones.

\section{Conclusion}

We think that the study of Albanian history in Rutul and in Dagestan is only at its beginning. Every home has many items of ancient utensils being passed on from generation to generation. People treat them as family heirloom and do not give to the museums. Every Dagestan home is like a museum itself, retaining many interesting facts for the history.

As the abovementioned material shows, the vocabulary of Rutul language has words which can shed light over religious beliefs of the people and their historical path. Due to absence of written sources, cave drawings and the language are very important evidences whish has not been properly studied.

\section{References}

Gurney O.R. The Hittites. Moscow. 1987.

Diakonova I. M. The Alarodians. VDM.1995. No. 2.

Ivanov V.V. The Hittite Language. Moscow. 2001. 294 p.

Hieromonch Alexy (Nikonorov). The History of Christianity in Caucasian Albania. Makhachkala, 2012.

Kilchevskaya E.V. From Pictorialism to an Ornament. Moscow, Nauka. 1968.

Kirakos of Gandzak. History. Translated into Russian by Ter-Grigoryan. Baku, 1946.

Klimov G.A. Problems of Deciphering of the Aghwan (Caucasian Albanian) Writing. Secrets of Ancient Writings. Moscow, 1976.

Klimov G.A. The Aghwan Language. World Languages. Caucasian Languages. Moscow, 1999.

Krabbe K. Notes to the Societies of Akhty, Rutul etc. TsGVIA, fund of VUA, K. 414, D. 301.

Kudriavtsev A.A. Ancient Derbent. Moscow, 1982.

Lavrov L.I. The Rutuls in the Past and Present. - The Caucasian Ethnographic Collection. Moscow-Leningrad. 1962.

Lolua R. Problems of Modern Studies of Albania. Udin Collection. Grammar. Vocabulary. History of the Language. Moscow, 2008.

Lolua R. Problems of Structure of Caucasian Albanian Language. Author's thesis. Tbilisi, 2010. 
Maisak T.A. To the Publication of Caucasian-Sinai Manuscripts from the Sinai Monastery. Voprosy Yazykoznaniya, No. 6, 2010.

Mammadova F.J. Christianity in Caucasian Albania. Baku, 2003.

Mammadova F.J. "History of the Albanians" by Movses Kaghankatvatsi as a Source of Information About Social System of Albania in Early-Middle Ages. Baku, 1977.

Mammadova F.J. Caucasian Albania and the Albanians. Baku, Research Centre of Caucasian Albania Studies, 2005.

Movses Kaghankatvatsi. "The History of the Country of Albania". Trans from Armenian. Yerevan, 1984.

Strabo. Geographica: in 17 books. Transl into Rus. Leningrad, Moscow, 1964. Book 11, Ch. 4.

Tokarev S.A. Religion in the World History. Moscow. 1964.

Trever K.V. An Outline of History and Culture of Caucasian Albania. Moscow- Leningrad. 1959.

Gippert J. et al. The Caucasian Albanian Palimpsests of Mt. Sinai. Brepols, 2008. 